\title{
A Critical Appraisal of the Threshold of Toxicity Model for Non- Carcinogens \\ Henk A Tennekes*
}

Experimental Toxicology Services (ETS) Nederland BV, Frankensteeg 4, 7201KN Zutphen, The Netherlands

\begin{abstract}
Most regulatory agencies assume that there is no safe level of exposure to carcinogens but that a threshold, or "safe" exposure level exists for non-carcinogens. However, recent discoveries have cast serious doubt on the validity of this concept. Five examples of non-carcinogens without an apparent threshold (neonicotinoids, dioxin, dieldrin, endocrine disruptors, and sulfhydryl-reactive metals) are presented. It is also clear by now that the threshold model for non-carcinogens may seriously underestimate actual risk. Risk assessments can no longer assume thresholds for non-carcinogens when the shape of the dose-response curve is linear at low concentrations. Risk management of such chemicals should be based on the ALARA principle ("as low as reasonably achievable").
\end{abstract}

Keywords: Risk Assessment; Threshold; Carcinogen; ALARA

\section{Introduction}

There is no universally accepted dose response model for risk assessment of low level exposures to potentially toxic substances, mainly because there is no consensus on presence or absence of a threshold below which no adverse effects can be assumed to occur. The issue is readily apparent in carcinogenic risk assessment. The dose-response model for carcinogenic risk assessment depends on absence or presence of genotoxic potential [1]. Non-genotoxic carcinogens (hormones, tumor promoters, TCDD as examples) are assumed to be characterized by a "conventional" dose-response relationship which allows derivation of a no-observed-adverse-effect-level (NOAEL), and an insertion of an uncertainty (or safety) factor permits the derivation of permissible exposure levels at which no relevant human cancer risks are anticipated [2]. A far more stringent dose-response model was widely adopted for genotoxic carcinogens.

The Genetics Panel of the U.S. National Academy of Sciences' Committee on Biological Effects of Atomic Radiation (BEAR) recommended the linear non-threshold (LNT) dose-response model in 1956, abandoning the threshold dose-response for genetic risk assessments [3]. This recommendation was adopted by the Atomic Energy Commission for estimates of the cancer risk from radioactive fallout [4]. The point of departure is the assertion that the doseresponse relationship for radiation-induced mutations is linear [5]. The NAS BEAR Committee Genetics Panel recommendation was quickly generalized to include somatic cells for cancer risk assessment and later was instrumental in the adoption of linearity for carcinogen risk assessment by the U. S. Environmental Protection Agency [6,7]. It was assumed that if "one hit" could cause a mutation and eventually result in cancer, then any exposure level could be associated with a finite cancer probability. The cancer risk assessment procedures adopted by the European Union scientific committee on occupational exposure limits (SCOEL) reserve the LNT dose-response model only for DNA reactive, tumour initiating genotoxic carcinogens, e.g., alkylating chemicals (vinyl chloride, 4-aminobiphenyl, diethylnitrosamine, acetaminofluorene, aflatoxin $\mathrm{B}_{1}$ ) or ionizing radiation [8]. SCOEL does, however, also recognize genotoxic carcinogens with a practical threshold (formaldehyde, vinyl acetate), and health-based exposure limits may then be based on an established NOAEL [8]. The LNT dose-response model has also been challenged by several authors who hypothesized potential thresholds and protective mechanisms throughout the process from initial DNA damage induction to tumor formation [9-13]. A sequential order of genome protection during carcinogenesis where genotoxicant scavenging, cellular efflux, DNA repair, elimination of damaged cells by apoptosis, autophagy, silencing by DNA damagetriggered replicative senescence, and finally, elimination of transformed (premalignant) cells by the immune system are thought to be responsible for a threshold in tumor formation. Within this context, the principle of Threshold of Toxicological Concern (TTC) has been developed by Kroes et al. [14]. The TTC approach applies a generic threshold for structural alerts of $0.15 \mu \mathrm{g} /$ person/day $(0.0025 \mu \mathrm{g} / \mathrm{kg} \mathrm{bw} /$ day) but excludes high-potency genotoxic substances, such as aflatoxinlike compounds, N-nitroso-compounds, and azoxy-compounds, from consideration [15]. The TTC concept has been used by the US Food and Drug Administration (FDA) to establish "thresholds of regulation" for indirect food additives as well as by the Joint FAO/WHO Expert Committee on Food Additives for flavoring substances. TTC has also been proposed for assessment of prenatal developmental toxicity [16], and for safety evaluation of cosmetic ingredients, pharmaceutical manufacturing operations $[17,18]$ and even for deriving target values for drinking water contaminants [19].

The threshold debate was compounded ever further by the observation that the neurotoxicity of non-genotoxic chemicals such as neonicotinoid insecticides and organic mercury may show doseresponse relationships identical to that of an alkylating $\mathrm{N}$-nitroso carcinogen such as diethylnitrosamine [20-23]. The common denominator of the dose-response relationship is irreversibility of receptor binding and irreversibility of the associated effect [21]. In fact, the discovery of the carcinogenicity of dimethylnitrosamine [24] which alkylates nucleic acids following enzymic hydroxylation [25], triggered the pharmacologist and cancer researcher Hermann Druckrey to put this concept to the test. Druckrey and Küpfmuller had hypothesized

*Corresponding author: Henk A Tennekes, Experimental Toxicology Services (ETS) Nederland BV, Frankensteeg 4, 7201KN Zutphen, The Netherlands, Tel: +31(0)575547717; E-mail: info@toxicology.nl

Received September 22, 2016; Accepted September 28, 2016; Published September 30, 2016

Citation: Tennekes HA (2016) A Critical Appraisal of the Threshold of Toxicity Model for Non-Carcinogens. J Environ Anal Toxicol 6: 408. doi: 10.4172/21610525.1000408

Copyright: ( 2016 Tennekes HA, et al. This is an open-access article distributed under the terms of the Creative Commons Attribution License, which permits unrestricted use, distribution, and reproduction in any medium, provided the original author and source are credited. 
Citation: Tennekes HA (2016) A Critical Appraisal of the Threshold of Toxicity Model for Non-Carcinogens. J Environ Anal Toxicol 6: 408. doi: 10.4172/2161-0525.1000408

Page 2 of 4

many years earlier with theoretical approaches to dose-response relationships that irreversible receptor binding with an associated irreversible effect would lead to reinforcement of the effect by exposure time [26] (Table 1).

Druckrey and his associates successfully validated the DruckreyKüpfmüller theorem in rat studies with diethylnitrosamine [27] and numerous other nitrosamines [28], as reflected in what is now known as the Druckrey-Küpfmüller equation:

$$
\mathrm{dt}^{\mathrm{n}}=\text { constant }
$$

where $\mathrm{d}=$ daily dose and $\mathrm{t}=$ exposure time to effect (liver cancer), and $\mathrm{n}=2.3$ (diethylnitrosamine)

There is no valid reason to assume a threshold for non-carcinogens when their dose - response relationships are identical to that of diethylnitrosamine and their mechanisms of action suggest irreversible receptor binding associated with irreversible effects. Moreover, there is increasing evidence to suggest that the threshold model may seriously underestimate actual risks. Five examples of non-carcinogens that may not have a threshold are discussed.

\section{Neonicotinoids}

Sanchez-Bayo [29] and Tennekes [20] recently demonstrated that equation (1) also describes the (neuro)toxicity of neonicotinoid insecticides in arthropods. Moreover, the mechanism of action also shows similarities with that of alkylating nitrosamines. The neonicotinoid insecticides block nicotinic acetylcholine (nACh) receptors in the central nervous system of insects [30] which leads to irreversible neuronal damage [31]. The affinity of the neonicotinoid imidacloprid for the nACh receptor in insects is very high, and, unlike the normal neurotransmitter acetylcholine, acetylcholinesterase can not remove imidacloprid from the $\mathrm{nACh}$ receptor, although this concept has recently been disputed [32] in spite of previous assertions [30,31] by Bayer experts of irreversible receptor binding. Dissociation, if it occurs at all, is bound to be very slow, and cumulative nACh receptor binding leading to irreversible neuronal toxicity can be easily envisaged [33].

Due to their environmental properties, neonicotinoids are threatening the survival of invertebrates. Several persistent neonicotinoids (imidacloprid, clothianidin, thiamethoxam) with time-cumulative toxicity to arthropods are prone to leach from soils [34], and have been demonstrated to contaminate surface water in Europe and North America [34,35]. In the Netherlands, surface water contamination with imidacloprid has been demonstrated to correlate with decline of macro-invertebrates [36] and insectivorous birds [34,37], and entomological surveys in Dutch and German nature reserves have revealed a staggering decline of ground beetles and flying insects since the introduction of this ubiquitous pesticide in agriculture in the early 1990s [34,38]. The risks of imidacloprid's time-cumulative toxicity to non-target insects have clearly been underestimated, and a revision of risk assessment is imperative. The Druckrey-Küpfmüller equation (1) with $\mathrm{n} \geq 1$ can serve as a dose-response model for risk assessment of compounds with time-cumulative toxicity. Carlborg pointed out that this equation is implied by a Weibull model for dose-response functions in carcinogenesis [39].

\section{Dioxin}

Lucier et al. [40] evaluated the effects of dioxins and pointed out that most, if not all, of dioxin's effects require interaction with a cellular protein, the Ah receptor. It is generally accepted that Ah receptor occupancy is linearly related to low cellular concentrations of dioxin [40]. Dioxin, like other Ah receptor agonists, induces an isoform of UDP-glucuronosyltransferase (UGT-1) by an Ah receptordependent mechanism [41]. This enzyme conjugates thyroxine (3,5,3',5'-tetraiodothyronine, T4), leading to its clearance. Metabolism of $\mathrm{T} 4$ and its consequent depletion from the blood relieves inhibition of TSH release from the pituitary by circulating T4 and causes the serum TSH concentration to rise, which is generally believed to promote the induction of thyroid tumors in rats and mice [41]. The low-dose linear responses of TSH and UGT-1 suggest the absence of a threshold for dioxin's effects on the thyroid [41].

\section{Dieldrin}

Similarly, the dose-response for promotion of liver tumor induction in mice by the non-genotoxic insecticide dieldrin was shown to be consistent with the absence of a threshold [42]. The accelerated velocity of liver tumor formation was shown to be linearly related to dieldrin dose.

\section{Endocrine Disruptors}

The absence of a threshold for endocrine disruption has also been demonstrated in an experiment concerning the regulation by estrogen of sex determination in reptiles [43]. Since endogenous estrogen is already above threshold for estrogen-mediated responses there can thus be no threshold for responses to exogenous chemicals that act as hormone mimics via estrogen receptor mechanisms [44].

\section{Sulfhydryl Reactive Metals}

In the case of organic mercury [23], the actual toxicant in the central nervous systems (CNS) is thought to be the divalent mercuric ion $\left(\mathrm{Hg}^{2+}\right)$ which is formed when organic mercury compounds such as methyl- and ethylmercury dealkylate. Once organic mercury compounds reach the brain tissue and dealkylate, $\mathrm{Hg}^{2+}$ gets trapped in the neurons, as it cannot permeate the blood-brain barrier. $\mathrm{Hg}^{2+}$ has electron-sharing facilities that can result in formation of covalent attachment to sulfhydryl groups of proteins, and binding of mercury species to thiol groups in amino acids, intracellular enzymes and structural proteins. It can be envisaged that mercury neurotoxicity could result from irreversible binding of mercuric ion to sulfhydryl groups of organic macromolecules [23].

Likewise, subtle effects on children's health of other sulfhydrylreactive metals, such as cadmium $(\mathrm{Cd})$, lead $(\mathrm{Pb})$, and arsenic $(\mathrm{As})$,

\begin{tabular}{|c|c|c|c|c|c|}
\hline $\begin{array}{l}\text { Reversibility of } \\
\text { receptor binding }\end{array}$ & $\begin{array}{l}\text { Receptor binding in relation } \\
\text { to compound concentration }\end{array}$ & $\begin{array}{l}\text { Reversibility of the } \\
\text { effect }\end{array}$ & $\begin{array}{l}\text { Effect in relation to } \\
\text { receptor binding }\end{array}$ & $\begin{array}{l}\text { Effect in relation } \\
\text { to compound } \\
\text { concentration }\end{array}$ & $\begin{array}{l}\text { Dose-response } \\
\text { characteristics }\end{array}$ \\
\hline \multirow[t]{2}{*}{$\mathrm{T}_{\mathrm{R}} \rightarrow 0$} & $C_{R} \sim C$ & $\mathrm{~T}_{\mathrm{r}} \rightarrow 0$ & $E \sim C_{R}$ & $E \sim C$ & Dose-dependent \\
\hline & & $\mathrm{T}_{\mathrm{r}} \rightarrow \infty$ & $E \sim \int C_{R} d t$ & $\mathrm{E} \sim \int \mathrm{C} d \mathrm{dt}$ & $\mathrm{Ct}=$ constant $^{\star}$ \\
\hline \multirow[t]{2}{*}{$\mathrm{T}_{\mathrm{R}} \rightarrow \infty$} & $\mathrm{C}_{\mathrm{R}} \sim \int \mathrm{Cdt}$ & $T_{r} \rightarrow 0$ & $E \sim C_{R}$ & $\mathrm{E} \sim \int \mathrm{C} d \mathrm{dt}$ & $\mathrm{Ct}=$ constant \\
\hline & & $T_{r} \rightarrow \infty$ & $E \sim \int C_{R} d t$ & $E \sim \iint C d t$ & Reinforced by time \\
\hline
\end{tabular}

$T_{R}$ is the time constant for the reversibility of receptor binding; $T$ is the time constant for the reversibility of the effect; $C_{R}$ is the concentration of bound receptors; $C$ is the concentration of the poison at the site of interaction. $\mathrm{E}=\mathrm{Effect}$; ${ }^{\prime} \mathrm{known}$ as Haber's Rule (the product of concentration and time produces a constant effect)

Table 1: Dose-response characteristics according to Druckrey and Küpfmüller [26]. 
Citation: Tennekes HA (2016) A Critical Appraisal of the Threshold of Toxicity Model for Non-Carcinogens. J Environ Anal Toxicol 6: 408. doi: 10.4172/2161-0525.1000408

Page 3 of 4

may not be associated with a threshold either [45-47]. The NRC panel concluded that linear models are most appropriate for dose-response modeling of mercury's neurodevelopmental effects in the absence of persuasive evidence supporting an alternative functional form [48].

\section{Conclusion}

Contrary to widely held belief, a threshold does not follow automatically from absence of genotoxic potential. The genotoxicity of an alkylating nitrosamine can be viewed as an example of irreversible receptor binding (covalent binding to DNA) associated with irreversible effects (gene mutations). Similar receptor-mediated mechanisms of toxic action are perfectly conceivable. Risk assessments should not assume thresholds for noncarcinogens as a matter of principle when there is mechanistic evidence of receptor-mediated toxicity [49]. If the shape of the dose-response curve conveys a linear relationship between receptor occupancy and biological response at lower concentrations, a threshold may not exist. This thesis constitutes a paradigm shift in a core area of toxicological sciences, but a linear doseresponse relationship cannot and must not be ignored and should be point of departure for effective risk management. For such chemicals, risk management should be based on the ALARA principle ("as low as reasonably achievable") unless benefits clearly outweigh risks, for example with pharmaceuticals for treatment of cancer or other lifethreatening diseases.

\section{References}

1. Tennant RW, Margolin BR, Shelby MD, Zeiger E, Haseman JK, et al. (1987) Prediction of chemical carcinogenicity in rodents from in vitro genetic toxicity assays. Science 236: 933-941.

2. Bolt HM, Foth H, Hengstler JG, Degen GH (2004) Carcinogenicity categorization of chemicals - new aspects to be considered in a European perspective. Toxicology Letters 151: 29-41.

3. Anonymous (1956) Genetic effects of atomic radiation. Summary Report of the Committee on Biological Effects of Atomic Radiation by the National Academy of Sciences, BEAR I Genetics Panel (W. Weaver, Chair). Science 124: 170.

4. Albert RE (1989) Carcinogen risk assessment. Environ Health Perspect 81: 103-105.

5. Calabrese EJ (2011) Muller's Nobel lecture on dose-response for ionizing radiation: ideology or science? Arch Toxicol 85: 1495-1498.

6. Environmental Protection Agency (EPA) (1976) Health risk and economic impact assessments of suspected carcinogens. Fed Regist 41: 21402-21405.

7. Environmental Protection Agency (EPA) (2005) Guidelines for Carcinogen Risk Assessment EPA/630/P-03/001F, 1-166

8. Bolt HM, Huici-Montagud A (2008) Strategy of the scientific committee on occupational exposure limits (SCOEL) in the derivation of occupational exposure limits for carcinogens and mutagens. Arch Toxicol 82: 61-64.

9. Thomas AD, Fahrer J, Johnson GE, Kaina B (2015) Theoretical considerations for thresholds in chemical carcinogenesis. Mutat Res Rev Mutat Res 765: 5667.

10. Calabrese EJ (2013) How the U.S. National Academy of Sciences mislead the world community on cancer risk assessment: New findings challenge historical foundations of the linear dose response. Arch Toxicol 87: 2063.

11. Calabrese EJ (2015) An abuse of risk assessment: how regulatory agencies improperly adopted LNT for cancer risk assessment. Arch Toxicol 89: 647-648.

12. Calabrese EJ (2009) The road to linearity: why linearity at low doses became the basis for carcinogen risk assessment. Arch Toxicol 83: 203-225.

13. Calabrese EJ, Baldwin LA (2003) Toxicology rethinks its central belief. Hormesis demands a reappraisal of the way risks are assessed. Nature 421: 691-692.

14. Kroes R, Galli C, Munro I, Schilter B, Tran LA, et al. (2000) Threshold of toxicological concern for chemical substances present in the diet: a practical tool for assessing the need for toxicity testing. Food and Chemical Toxicology 38: $255-312$.
15. Kroes R, Kleiner J, Renwick A (2005) The threshold of toxicological concern concept in risk assessment. Toxicol Sci 86: 226-230.

16. van Ravenzwaay B, Dammann M, Buesen R, Schneider S (2011) The threshold of toxicological concern for prenatal developmental toxicity. Regul Toxicol Pharmacol 59: 81-90.

17. Kroes R, Renwick AG, Feron V, Galli CL, Gibney M, et al. (2007) Application of the threshold of toxicological concern (TTC) to the safety evaluation of cosmetic ingredients. Food Chem Toxicol 45: 2533-2562.

18. Dolan DG, Naumann BD, Sargent EV, Maier A, Dourson M (2005) Application of the threshold of toxicological concern concept to pharmaceutical manufacturing operations. Regul Toxicol Pharmacol 43: 1-9.

19. Mons MN, Heringa MB, van Genderen J, Puijker LM, Brand W, et al. (2013) Use of the Threshold of Toxicological Concern (TTC) approach for deriving target values for drinking water contaminants. Water Research 47: 1666 -1678.

20. Tennekes HA (2010) The significance of the Druckrey-Kupfmuller equation for risk assessment - the toxicity of neonicotinoid insecticides to arthropods is reinforced by exposure time. Toxicology 276: 1-4.

21. Tennekes HA, Sánchez-Bayo F (2012) Time-dependent toxicity of neonicotinoids and other toxicants: Implications for a new approach to risk assessment. Journal of Environmental \& Analytical Toxicology S4-001.

22. Tennekes HA, Sánchez-Bayo F (2013) The molecular basis of simple relationships between exposure concentration and toxic effects with time. Toxicology 309: 39-51.

23. Pletz J, Sánchez-Bayo F, Tennekes HA (2016) Dose-response analysis indicating time-dependent neurotoxicity caused by organic and inorganic mercuryImplications for toxic effects in the developing brain. Toxicology 347: 1-5.

24. Magee PN, Barnes JM (1956) The production of malignant primary hepatic tumours in the rat by feeding dimethylnitrosamine. $\mathrm{Br} J$ Cancer 10: 114-122.

25. Magee PN, Farber E (1962) Toxic liver injury and carcinogenesis. Methylation of rat-liver nucleic acids by dimethylnitrosamine in vivo. Biochem J 83: 114-124.

26. Druckrey H, Küpfmüller K (1949) Dosis und Wirkung: Beiträge zur theoretischen Pharmakologie. Editio Cantor GMBH.

27. Druckrey VH, Schildbach A, Schmaehl D, Preussmann R, Ivankovic S (1963) Quantitative analysis of the carcinogenic effect of diethylnitrosamine Arzneimittel-Forschung 13: 841-851.

28. Druckrey H, Preussmann R, Ivankovic S, Schmähl D (1967) Organotropic carcinogenic effects of 65 various $\mathrm{N}$-nitroso-compounds on $\mathrm{BD}$ rats. Zeitschrift für Krebsforschung 69: 103-201.

29. Sánchez-Bayo F (2009) From simple toxicological models to prediction of toxic effects in time. Ecotoxicology 18: 343-354.

30. Abbink J (1991) The Biochemistry of Imidacloprid. Pflanzenschutz-Nachrichten Bayer, Germany, F.R. ISSN: 0340-1723.

31. Mehlhorn H, Mencke N, Hansen O (1999) Effects of imidacloprid on adult and larval stages of the flea Ctenocephalides felis after in vivo and in vitro application: a light-and electron-microscopy study. Parasitol Res 85: 625-637.

32. Maus C, Nauen R (2011) Response to the publication: Tennekes, HA (2010) the significance of the Druckrey-Küpfmüller equation for risk assessment-the toxicity of neonicotinoid insecticides to arthropods is reinforced by exposure time. Toxicology 280: 176-177.

33. Tennekes HA (2011) The significance of the Druckrey-Küpfmüller equation for risk assessment-The toxicity of neonicotinoid insecticides to arthropods is reinforced by exposure time: Responding to a Letter to the Editor by Drs. C. Maus and R. Nauen of Bayer CropScience AG. Toxicology 280: 173-175.

34. Tennekes HA (2010) The Systemic Insecticides: A Disaster in the Making. Zutphen, The Netherlands: ETS Nederland BV.

35. Morrissey CA, Mineau P, Devries JH, Sanchez-Bayo F, Liess M, et al. (2015) Neonicotinoid contamination of global surface waters and associated risk to aquatic invertebrates: a review. Environ Int 74: 291-303.

36. Van Dijk TC, Van Staalduinen MA, Van der Sluijs JP (2013) Macro-invertebrate decline in surface water polluted with imidacloprid. PLoS One 8: e62374.

37. Hallmann CA, Foppen RP, van Turnhout CA, de Kroon $H$, Jongejans $E$ (2014) Declines in insectivorous birds are associated with high neonicotinoid concentrations. Nature 511: 341-343. 
Citation: Tennekes HA (2016) A Critical Appraisal of the Threshold of Toxicity Model for Non-Carcinogens. J Environ Anal Toxicol 6: 408. doi: $10.4172 / 2161-0525.1000408$

Page 4 of 4

38. Sorg M, Schwan H, Stenmans W, Müller A (2013) Ermittlung der Biomassen flugaktiver Insekten im Naturschutzgebiet Orbroicher Bruch mit Malaise Fallen in den Jahren 1989 und 2013. Mitteilungen aus dem Entomologischen Verein Krefeld 1: 1-5.

39. Carlborg FW (1981) Dose-response functions in carcinogenesis and the Weibull model. Food Cosmet Toxicol 19: 255-263.

40. Lucier GW, Portier CJ, Gallo MA (1993) Receptor mechanisms and doseresponse models for the effects of dioxins. Environ Health Perspect 101: 36-44.

41. Melnick RL, Kohn MC, Portier CJ (1996) Implications for Risk Assessment of Suggested Nongenotoxic Mechanisms of Chemical Carcinogenesis. Environ Health Perspect 104: 123-134.

42. Tennekes H, van Ravenzwaay B, Kunz HW (1985) Quantitative aspects of enhanced liver tumour formation in CF-1 mice by dieldrin. Carcinogenesis 6 : 1457-1462.

43. Sheehan DM, Willingham E, Gaylor D, Bergeron JM, Crews D (1999) No threshold dose for estradiol-induced sex reversal of turtle embryos: how little is too much? Environ Health Perspect 107: 155-159.
44. Welshons WV, Thayer KA, Judy BM, Taylor JA, Curran EM, et al. (2003) Large effects from small exposures. I. Mechanisms for endocrine-disrupting chemicals with estrogenic activity. Environ Health Perspect 111: 994-1006.

45. de Burbure C, Buchet JP, Leroyer A, Nisse C, Haguenoer JM, et al. (2006) Renal and neurologic effects of cadmium, lead, mercury, and arsenic in children: evidence of early effects and multiple interactions at environmental exposure levels. Environ Health Perspect 114: 584-590.

46. Bernard A, Thielemans N, Roels H, Lauwerys R (1995) Association between NAG-B and cadmium in urine with no evidence of a threshold. Occup Environ Med 52: 177-180.

47. Quig D (1998) Cysteine metabolism and metal toxicity. Altern Med Rev 3: 262270.

48. NRC (National Research Council) (2000) Toxicological Effects of Methylmercury. Washington, DC: National Academy Press.

49. Wigle DT, Lanphear BP (2005) Human health risks from low-level environmental exposures: no apparent safety thresholds. PLoS Med 2: e350. 